\title{
PENGARUH JAM BACA TERHADAP IPK MAHASISWA FEB UNPAD
}

\author{
Siska Musdalifah ${ }^{1}$, Estro Dariatno Sihaloho ${ }^{2}$ \\ ${ }_{1,2}$ Departemen Ilmu Ekonomi, Fakultas Ekonomi dan Bisnis, Universitas Padjadjaran \\ e-mail: siska17001@mail.unpad.ac.id
}

\begin{abstract}
Abstrak
Untuk mendapatkan jumlah IPK yang memuaskan, mahasiswa perlu melakukan berbagai usaha. Salah satu usaha yang dapat dilakukan ialah belajar, dalam proses belajar tersebut diperlukan minat baca. Penelitian ini bertujuan untuk menjelaskan pengaruh jam baca terhadap besarnya IPK yang diperoleh mahasiswa Fakultas Ekonomi dan Bisnis Universitas Padjajaran. Jam baca dalam penelitian ini merupakan pengasumsian dari seberapa besar minat baca yang dimiliki mahasiswa tersebut. Analisisnya menggunakan lama waktu yang dihabiskan untuk membaca, lama waktu kuliah dan partisipasi dalam organisasi sebagai variabel independen. Sampel penelitian ini adalah mahasiswa mahasiswi aktif di Fakultas Ekonomi dan Bisnis Universitas Padjajaran. Jenis data yang digunakan dalam penelitian ini adalah data kuantitatif dan bersumber dari data primer. Pengumpulan data dilakukan dengan menggunakan kuesioner yang disebarkan langsung ke 111 mahasiswa aktif. Analisis data menggunakan regresi linear berganda (Multiple Regression Model) dengan metode OLS (Ordinary Least Squares) menggunakan bantuan software Stata versi 15 for windows. Hasil pengujian menunjukan bahwa secara parsial, lama waktu yang dihabiskan untuk membaca, lama waktu kuliah dan partisipasi dalam organisasi berpengaruh secara signifikan terhadap IPK yang diperoleh mahasiswa Fakultas Ekonomi dan Bisnis Universitas Padjajaran. Sementara secara simultan, lama waktu yang dihabiskan untuk membaca, lama waktu kuliah dan partisipasi dalam organisasi berpengaruh juga secara signifikan terhadap IPK yang diperoleh mahasiswa Fakultas Ekonomi dan Bisnis Universitas Padjajaran.
\end{abstract}

Kata Kunci: waktu membaca, minat baca, lama kuliah, partisipasi dalam organisasi, IPK

\section{PENDAHULUAN}

Pendidikan merupakan salah satu aspek penting yang berusaha dipenuhi oleh setiap orang. Selain itu, pendidikan merupakan wadah untuk meningkatkan kualitas sumber daya manusia agar salah tujuan pembangunan nasional tercapai (Parmadani \& Latifah, 2016). Ketika seseorang menjalani pendidikan, mereka cenderung menginginkan hasil belajar yang baik. Untuk mendapatkan hasil belajar yang baik maka diperlukannya minat baca (Slameto, 2010). Minat baca yang tinggi dapat memperluas pengetahuan dan meningkatkan hasil belajar seseorang secara optimal (Listariono, 2010), hal ini sejalan dengan slogan membaca yang populer yaitu membaca adalah jendela dunia. Mahasiswa perlu membaca buku agar dapat lulus dengan hasil yang memuaskan (Siregar, 2008). Mahasiswa yang tidak dapat menjawab ataupun memberikan pertanyaan ketika proses belajar mengajar berlangsung memiliki kemungkinan besar bahwa mahasiswa tersebut tidak membaca buku (Siswati, 2010). Sebagai bagian dari masyarakat akademis, mahasiswa diwajibkan untuk membaca (Siregar, 2008). Menurut Leonhard, ketika seseorang gemar membaca maka ia akan senantiasa unggul dalam kelas (dalam AR, 2017). Asnita berpendapat bahwa jika seseorang tidak memiliki minat baca yang tinggi sejak dini maka ia akan mengalami kesulitan dalam proses belajar mengajar (dalam AR, 2017). Minat baca yang rendah dapat menyebabkan mahasiswa mendapatkan hasil belajar yang kurang memuaskan atau bahkan mutu pendidikan yang rendah karena rendahnya minat baca menandakan bahwa mahasiswa tersebut malas untuk belajar. Perlu diingat bahwa tujuan dari proses pembelajaran sendiri adalah nilai atau hasil belajar yang baik. 
Sebuah negara dapat dikatakan maju bila rakyatnya gemar membaca, hal ini terbukti dari berapa jumlah perpustakaan yang ada dan jumlah buku yang diterbitkan oleh negara tersebut (AR, 2017). Minat membaca masyarakat Indonesia masih memprihatinkan, pada studi World Most Literate Countries tahun 2016 yang dilakukan oleh Presiden Central Connecticut State University (CCSU), John W. Miller, Indonesia menempati peringkat 60 dari 61 negara. Ini berarti peringkat Indonesia hanya berada diatas satu negara saja, yaitu Negara Botswana. Sementara itu, hasil survey dari Badan Pusat Statistik (BPS) pada tahun 2012 menemukan bahwa masyarakat Indonesia belum menjadikan membaca sebagai sumber utama untuk mendapatkan informasi, masyarakat Indonesia cenderung lebih senang untuk menonton televisi dan mendengarkan radio (AR, 2017). Padahal, masyarakat yang gemar membaca sangat diperlukan untuk memajukan bangsa Indonesia sendiri. Gemar membaca dapat diperoleh ketika seseorang memiliki minat baca dan menjadikannya kegiatan yang biasa dilakukan (AR, 2017), hal ini sejalan dengan pendapat Nurhadi yang menyatakan besarnya minat membaca akan menimbulkan kebiasaan membaca (dalam Nurhadi, 2008). Salah satu cara untuk menimbulkan perasaan gemar membaca yaitu diterapkannya kebiasaan membaca sejak dini (AR, 2017).

Hal ini tidak menutup kemungkinan bahwa besarnya IPK yang diperoleh mahasiswa Fakultas Ekonomi dan Bisnis Universitas Padjajaran dipengaruhi oleh minat baca mahasiswanya itu sendiri. Besarnya minat baca dari mahasiswa dapat digambarkan melalui lamanya waktu yang rela dihabiskan mahasiswa untuk membaca. Hal ini sejalan dengan pendapat Dalman yaitu tingkat frekuensi membaca dan kuantitas sumber bacaan dapat digunakan sebagai indikator tinggi atau rendahnya minat baca seseorang (dalam Dalman, 2013). Semakin besar waktu yang dihabiskan untuk membaca dalam sehari maka semakin besar pula minatnya dalam membaca. Penelitian ini menganalisis bagaimana pengaruh lama waktu yang dihabiskan untuk membaca, lama waktu kuliah dan partisipasi dalam organisasi terhadap besarnya IPK yang diperoleh mahasiswa Fakultas Ekonomi dan Bisnis Universitas Padjajaran.

\section{STUDI LITERATUR}

\section{a. Minat}

Keinginan dan kebutuhan terhadap suatu objek akan menimbulkan minat seseorang (Sardiman, 2000). Menurut Kamus Besar Bahasa Indonesia, arti dari kata minat adalah kecenderungan hati yang tinggi atau keinginan terhadap sesuatu (Depdikbud, 2016). Minat merupakan rasa keterikatan dan kecenderungan lebih suka pada suatu hal atau aktivitas tanpa ada yang menyuruh (Slameto, 2010). Minat adalah kekuatan dan dorongan untuk memperhatikan dan tertarik pada berbagai kegiatan untuk memenuhi tuntutan sosial yang ada (Sari \& Wakijo, 2017). Minat diartikan sebagai kecenderungan rasa tertarik pada subyek dibidang atau hal tertentu yang memberikan perasaan senang (Winkel, 2004). Minat adalah rasa tertarik dan kecenderungan menyenangi suatu objek dari dalam diri individu (Suryabrata, 2005). Menurut Moh. As'ad, minat merupakan objek situasi atau ide-ide tertentu yang membuat seseorang merasa senang (Achmadi, 2007). Pada dasarnya, minat itu penerimaan hubungan antara diri sendiri dengan sesuatu selain dirinya sendiri (Djamarah, 2008). Minat digambarkan oleh Getzels sebagai disposisi khas yang terbentuk melalui pengalaman individu itu sendiri dan mendorong individu untuk menguasai dan memahami objek tertentu sebagai hasil perhatian yang ditimbulkannya (dalam Siswati, 2010). Minat mengarahkan dan mendorong tindakan kepada suatu tujuan (Purwanto, 2007). Menurut Tidjan, minat merupakan gejala psikologis dimana perasaan senang merupakan alasan pemusatan perhatian terhadap suatu objek (dalam Widyasmoro, 2014). Minat merupakan gairah yang cenderung tinggi pada sesuatu (Achmadi, 2007). Secara sederhana, minat adalah kecenderungan dan gairah yang tinggi pada sesuatu (Syah, 2010). 
Faktor yang mempengaruhi minat ialah kondisi fisik, kondisi mental, kesiapan dalam belajar dan pengalaman seseorang (Hardi, 2014). Jika minat tidak disalurkan dengan baik, minat dapat menghilang begitu saja, karena motivator dan pendorong seseorang dalam melakukan kegiatan adalah minat (Hapsari, Sayidati \& Rachmawati, 2018). Minat bukan hanya mempengaruhi motivasi seseorang dalam kerelaan terikat suatu kegiatan, melainkan dapat mempengaruhi perilaku seseorang (Hardi, 2014). Maka dapat disimpulkan bahwa minat adalah keinginan dari dalam diri sendiri terhadap sesuatu tanpa adanya paksaan dari pihak manapun yang diiringi oleh perasaan senang.

\section{b. Membaca}

Menurut Kamus Besar Bahasa Indonesia, arti dari kata baca atau membaca adalah melihat serta memahami isi dari apa yang tertulis dengan melafalkan apa yang tertulis atau hanya dalam hati (Depdikbud, 2016). Membaca adalah proses pencarian makna hingga didapatkannya pesan dari penulis yang dilakukan melalui penghubungan kata tulis dengan makna bahasa lisan (Widyasmoro, 2014). Keterampilan yang perlu dikembangkan melalui proses belajar secara bertahap dan waktu yang panjang adalah membaca (Amanah, Noviana, Sofiah, \& Chamdani, 2018). Menurut Anderson Richard, membaca merupakan pembentukan arti dari teks tertulis (dalam Wiryodijoyo, 1989). Menurut Lado, membaca ialah memahami berbagai pola bahasa dari tulisan (dalam Tarigan, 2008). Menurut Carter, membaca adalah proses mengartikan, menafsirkan dan menerapkan ide dari lambang dalam pikiran (dalam Wiryodijoyo, 1989). Menurut Hodgson, membaca merupakan sebuah proses dimana pembaca mendapatkan pesan yang ingin disampaikan oleh penulis melalui media tulis (dalam Tarigan, 2008). Menurut Heilman, membaca merupakan proses menemukannya arti dari kata yang ditulis (dalam Wiryodijoyo, 1989). Menurut Carol, membaca adalah proses penerjemahan dan pemahaman (dalam Wiryodijoyo, 1989). Menurut Cole, membaca adalah penentuan arti dari kata-kata tertulis yang termasuk ke dalam proses psikologis (dalam Wiryodijoyo, 1989). Maka dapat disimpulkan bahwa membaca adalah proses pemahaman makna dan penafsiran dari rangkaian kata yang penulis berusaha sampaikan.

\section{c. Minat Baca}

Proses dan keinginan yang kuat dari diri sendiri sangat diperlukan untuk memunculkan minat baca. Minat baca merupakan aktivitas yang memerlukan ketekunan penuh untuk membentuk pola komunikasi dengan diri sendiri agar didapatkannya makna dan informasi tulisan untuk mengembangkan intelektualitas dan perasaan senang didalam diri sendiri (Dalman, 2013). Secara sederhana, minat baca ialah keinginan yang kuat diiringi oleh berbagai usaha individu untuk membaca (Rahim, 2009). Berkeinginan kuat untuk mencari kesempatan untuk membaca kapan saja dan dimana saja merupakan minat baca (Djamarah, 2011). Minat membaca adalah suatu perhatian individu yang kuat dan mendalam diiringi dengan perasaan senang pada kegiatan membaca hingga mengarahkan individu tersebut untuk membaca dengan kemauannya sendiri maupun dibantu dorongan dari luar (Wahadaniah, 1997). Minat baca merupakan keinginan disertai usaha untuk membaca (Amanah et al., 2018). Minat membaca adalah keinginan yang kuat dari dalam diri sendiri tanpa adanya paksaan untuk melakukan aktivitas membaca (Sari \& Wakijo, 2017). Menurut Rosyidi, minat membaca yang tinggi dapat memberikan harapan yang tinggi terhadap kesuksesan termasuk hasil belajar seseorang (dalam Hardi, 2014). Maka dapat disimpulkan bahwa minat baca adalah suatu keinginan seseorang untuk membaca tanpa adanya paksaan dari pihak manapun dan jika keinginan membacanya terpenuhi maka seseorang tersebut akan merasa senang. Indikator minat baca menurut Crow and Crow ialah motivasi, perasaan, penghabisan waktu, perhatian pada membaca, kuatnya emosi dalam membaca dan usaha dalam membaca (Hapsari, Sayidati \& Rachmawati, 2018). 


\section{d. Prestasi}

Menurut Kamus Besar Bahasa Indonesia, arti dari kata prestasi adalah hasil yang telah dicapai dari apa yang telah dikerjakan (Depdikbud, 2016). Prestasi merupakan pembuktian dari berbagai usaha yang telah dilakukan (Winkel, 2004). Prestasi adalah tingkat dari keberhasilan dalam mencapainya suatu tujuan (Syah, 2010). Prestasi merupakan hasil interaksi berbagai faktor dalam mempengaruhi individu dalam belajar (Sardiman, 2000). Prestasi merupakan hasil secara individual maupun kelompok dari kegiatan yang telah dilaksanakan (Budisetyani, 2005). Menurut Sumadi Suryabrata, kemampuan, keterampilan dan sikap seseorang untuk membereskan suatu hal disebut prestasi (dalam Nugroho, 2012). Menurut Tabriani, prestasi merupakan kemampuan nyata yang diperoleh melalui suatu usaha (Widyasmoro, 2014). Prestasi digunakan sebagai pencapaian keberhasilan dari suatu tujuan (Widodo, 2000). Maka dapat disimpulkan bahwa prestasi adalah hasil pembuktian kerja keras seseorang terhadap suatu hal yang sedang digelutinya.

\section{e. Belajar}

Belajar dimulai ketika individu lahir ke dunia hingga akhir hayatnya (Komarudin, 2018). Apabila individu tidak dapat melakukan sesuatu atau mengerti sesuatu melalui reflek atau kebiasaan maka individu tersebut perlu belajar (Witherrington, 1959). Interaksi dari stimulus dan respon mengakibatkan seseorang belajar (Slavin, 2000). Untuk mendapatkan perubahan tingkah laku, keterampilan, kemampuan dan sifat-sifat yang lebih baik diperlukan proses aktivitas dengan memberdayakan panca indra yang disebut belajar (Sriyono, 2011). Proses agar tercapainya berbagai macam kompetensi, sikap dan keterampilan disebut belajar (Baharuddin \& Wahyuni, 2008). Menurut Kamus Besar Bahasa Indonesia, arti dari kata belajar adalah usaha mendapatkan ilmu (Depdikbud, 2016). Belajar merupakan proses perubahan yang berlangsung dalam jangka waktu tertentu, dari yang sebelumnya tidak bisa menjadi bisa (Winkel, 2004). Belajar adalah proses yang dijalankan individu untuk mendapatkan perubahan tingkah laku sebagai hasil pengalaman dalam interaksi dengan lingkungannya (Slameto, 2010). Belajar merupakan proses perubahan perilaku aktual atau potensial yang dipengaruhi banyak faktor (Herkusumo, 2009). Belajar merupakan pengalaman dan latihan yang merubah perilaku (Djamarah, 2008). Belajar merupakan proses mencari ilmu agar diri berubah menjadi yang lebih baik (Asmani, 2009). Proses memperoleh pengetahuan, keterampilan dan kepribadian disebut belajar (Suyono \& Hariyanto, 2011). Menurut Ferrari, belajar adalah proses yang dipengaruhi faktor internal dan faktor eksternal untuk mengubah tingkah laku siswa dengan bantuan guru (dalam Wulan, 2000). Belajar merupakan proses dan unsur yang sangat fundamental dalam setiap jenjang pendidikan (Suprayekti, 2010). Menurut Abdillah, belajar merupakan usaha yang dilakukan seseorang dalam merubah tingkah laku melalui latihan dan pengalaman (dalam Aunurrahman, 2010). Menurut Cronbach, belajar adalah pengalaman yang mengubah perilaku (dalam Suryabrata, 2005). Menurut Skinner, belajar merupakan penyesuaian tingkah laku secara progresif (dalam Syah, 2010). Menurut Gagne, belajar merupakan keadaan stimulus dengan isi pikiran yang mempengaruhi seseorang sehingga berubahnya tingkah laku dari waktu ke waktu (dalam Dalyono, 2005). Menurut Aisyah dan Fatimah, belajar merupakan latihan atau pengalaman yang menyebabkan suatu perubahan (dalam Wirantasa, 2018). Menurut Hintzman, belajar ialah pengalaman yang mempengaruhi sehingga terjadinya perubahan dalam diri seseorang (dalam Syah, 2010). Menurut Hilgard, belajar merupakan suatu kegiatan yang berubah melalui prosedur latihan (dalam Suryabrata, 2005). Menurut Hilgard, belajar memiliki hubungan dengan berubahnya tingkah laku seseorang terhadap situasi tertentu yang disebabkan oleh pengalaman (dalam Dalyono, 2005). Maka dapat 
disimpulkan bahwa belajar adalah proses ketekunan seseorang untuk bisa melakukan atau mengerti hal yang baru.

\section{f. Prestasi Belajar}

Dalam dunia perkuliahan, prestasi belajar mahasiswa diukur menggunakan Indeks Prestasi Kumulatif (IPK). Pengertian prestasi belajar sendiri adalah hasil belajar peserta didik yang menjadi indikator kompetensi dan derajat perubahan perilaku (Darmadi, 2012). Atau dapat dikatakan sebagai kemampuan siswa setelah ia melakukan pembelajaran (Sudjana, 2013). Menurut Djaelani dan Mahfud, prestasi belajar merupakan angka yang diberikan guru dari penguasaan pengetahuan individu (Wirantasa, 2018). Prestasi belajar adalah penguasaan individu terhadap pelajaran yang ditandai dengan perkembangan dan perubahan tingkah laku individu (Slameto, 2010). Prestasi Belajar merupakan nilai yang diberikan guru kepada siswa sebagai hasil yang telah dicapai dari mengikuti kegiatan pembelajaran (Tu'u, 2004). Prestasi belajar adalah rapor hasil usaha belajar seseorang (Purwanto, 2007). Prestasi belajar merupakan bukti hasil kemampuan siswa dalam kegiatan belajarnya (Winkel, 2004). Hasil yang diperoleh merupakan prestasi yang telah diukur (Timperley \& Alton-Lee, 2008). Prestasi belajar adalah nilai hasil tes yang merupakan taraf keberhasilan murid dalam pelajaran (Syah, 2010). Prestasi belajar merupakan hasil yang didapatkan siswa dari tes belajar yang menyatakan 60\% penguasaan terhadap materi pelajaran (Nelsusmena, 2010). Kesempurnaan yang diperoleh dari pikiran, perasaan dan perbuatan (Nasution, 1996). Prestasi belajar adalah hasil kegiatan yang telah dilakukan baik secara individu maupun kelompok (Hamdani, 2011). Hasil belajar yang dicapai siswa dalam periode waktu tertentu biasanya berupa angka merupakan prestasi belajar (Tarno, 2010). Menurut Hasan Alwi, prestasi belajar merupakan pengembangan pengetahuan dan keterampilan melalui mata pelajaran yang hasilnya disajikan sebagai nilai (dalam Slameto, 2010). Bertujuan untuk mencapai hasil yang sesuai dengan target berupa skor yang berasal dari standar tes (van Geel, Keuning, Visscher, \& Fox, 2016). Maka dapat disimpulkan bahwa prestasi belajar bagi mahasiswa adalah bukti penguasaan individu terhadap suatu mata pelajaran dalam bentuk Indeks Prestasi Kumulatif (IPK). Faktor-faktor yang menentukan prestasi belajar mahasiswa adalah minat dari diri sendiri, lingkungan yang mendukung suasana belajar dan strategi pembelajaran mahasiswa itu sendiri (Achmadi, 2007).

\section{METODE}

\section{a. Jenis dan Sumber Data}

Jenis data yang digunakan dalam penelitian ini adalah data kuantitatif. Data kuantitatif merupakan data yang dinyatakan dalam bentuk angka-angka dan dapat diukur, bukan dalam bentuk bilangan (Noor, 2014). Data kuantitatif dalam penelitian ini berupa data cross section. Data cross section terdiri dari sampel individu, rumah tangga, perusahaan, kota, negara, atau berbagai unit lainnya, diambil pada titik waktu tertentu, terkadang, data yang diperoleh tidak memiliki periode waktu yang sama persis (Wooldridge, 2012).

Data penelitian ini bersumber dari data primer. Data primer merupakan data yang diperoleh pihak pertama melalui wawancara, kuesioner dan lain-lain (Suharsimi, 2010). Data dalam penelitian ini diperoleh pada bulan April 2019, menggunakan kuesioner yang respondennya terdiri dari 111 mahasiswa aktif di Fakultas Ekonomi dan Bisnis Universitas Padjajaran.

\section{b. Alat Analisis}

Alat analisis yang digunakan ialah metode OLS (Ordinary Least Squares). Metode OLS merupakan salah satu metode yang digunakan dalam analisis regresi linear berganda (Multiple 
Regression Model), cara yang digunakan untuk memperkirakan garis regresi adalah dengan mencari nilai minimal untuk jumlah kuadrat kesalahan antara nilai yang diprediksikan dengan nilai sebenarnya. Model Ekonometrik yang digunakan dalam penelitian ini adalah sebagai berikut:

Keterangan:

$$
I P K_{i}=\beta_{0}+\beta_{1} W B_{i}+\beta_{2} L K_{i}+\beta_{3} P O_{i}+u_{i}
$$

IPK : merupakan IPK mahasiswa

WB : merupakan lama waktu yang dihabiskan untuk membaca

LK : merupakan lama waktu kuliah

PO : merupakan partisipasi mahasiswa dalam organisasi

$u \quad$ : merupakan error

Sebelum dilakukan pengolahan data menggunakan metode OLS, seluruh data tersebut harus memenuhi semua asumsi dasar model OLS dengan melakukan uji multikolinearitas dan uji heteroskedastisitas.

\section{c. Uji Asumsi Klasik}

Uji Asumsi Klasik dilakukan untuk mengetahui apakah model regresi yang digunakan dalam penelitian ini menghasilkan estimator linier yang baik. Jika model memenuhi semua asumsi klasik, maka model regresi ideal atau BLUE (Best, Linear, Unbiased, Estimator).

i. Uji Multikolinearitas

Multikolinearitas merupakan situasi dimana korelasi yang tinggi terjadi antar dua atau lebih variabel independen (Wooldridge, 2012). Multikolinearitas terjadi karena beberapa atau mungkin semua variabel independen dalam model terdapat hubungan linear yang "sempurna" (Gujarati \& Porter, 2008).

Cara menguji multikolinearitas adalah dengan melihat nilai dari mean VIF (Variance Inflation Factors), melihat sejauh mana sebuah variabel independen dapat dijelaskan dengan semua variabel independen lainnya dalam persamaan regresi. Jika nilai $R^{2}$ lebih kecil atau sama dengan $80 \%$ dan nilai mean VIF lebih kecil atau sama dengan 5 maka dapat dipastikan bahwa tidak terdapat multikolinearitas dalam model. Dan jika nilai $R^{2}$ lebih kecil atau sama dengan $90 \%$ dan nilai mean VIF lebih kecil atau sama dengan 10 maka dapat dipastikan bahwa tidak terdapat masalah multikolinearitas dalam model.

\section{ii. Uji Heteroskedastisitas}

Heteroskedastisitas terjadi apabila kesalahan atau residual dari model yang diamati tidak konstan dari satu observasi ke observasi lainnya. Konsekuensi yang harus dihadapi apabila terdapat masalah heteroskedastisitas adalah nilai $S_{e}$ menjadi bias, dan otomatis nilai t menjadi tidak valid, karena nilai t dihasilkan dari hasil bagi $\beta_{i}$ dan $S_{e}$.

Cara mendeteksi heteroskedastisitas pada error term dengan variabel independen yang bersifat linear adalah dengan menggunakan uji Breusch Pagan test (BP Test) sementara itu apabila diasumsikan ada hubungan fungsional yang kuadratik antara error term dengan variabel independen dan atau terdapat interaksi antar variabel independen (cross product) maka pengujian menggunakan White Test. Kriteria dari kedua pengujian tersebut ialah apabila nilai pada LM lebih kecil daripada 
nilai chi-square table dan atau nilai $p$-value lebih besar daripada nilai $\alpha$ (tingkat signifikansinya) maka tidak terdapat masalah heteroskedastisitas dalam model.

\section{d. Uji Hipotesis}

\section{i. $\quad$ Uji Signifikansi Parameter Individual (Uji Statistik t)}

Uji t dilakukan untuk melihat bagaimana pengaruh setiap variabel independen secara individual menjelaskan variasi variabel dependen (Kuncoro, 2009). Menurut kriteria uji statistik t, ketika nilai t hitung lebih besar nilainya daripada $t$ tabel atau nilai t hitung lebih kecil nilainya daripada $\mathrm{t}$ tabel negatif maka dapat dipastikan bahwa antara variabel independen dan variabel dependen terdapat pengaruh yang signifikan.

\section{ii. $\quad$ Uji Signifikansi Simultan (Uji Statistik F)}

Uji $\mathrm{F}$ dilakukan untuk melihat apakah seluruh variabel independen memiliki pengaruh simultan (bersama-sama) terhadap variabel dependen (Kuncoro, 2009). Menurut kriteria uji statistik F, ketika nilai $\mathrm{F}$ hitung lebih besar daripada $\mathrm{F}$ tabel maka dapat dipastikan bahwa minimal terdapat satu variabel independen yang memiliki pengaruh terhadap variabel dependen.

\section{iii. $\quad$ Uji Koefisien Determinasi $\left(R^{2}\right)$}

Uji $R^{2}$ dilakukan untuk melihat seberapa besar variasi dari seluruh variable independen dalam model dapat menjelaskan variasi dari variabel dependen. Jika nilai $R^{2}$ mendekati satu maka model hampir mampu memberikan seluruh variabel independen yang dibutuhkan untuk memprediksi variasi variabel dependen (Kuncoro, 2009).

\section{HASIL DAN PEMBAHASAN}

\section{a. Deskripsi Statistik}

Berdasarkan data yang telah dikumpulkan peneliti, diperoleh hasil deskripsi statistik IPK mahasiswa, lama waktu yang dihabiskan untuk membaca, lama waktu kuliah dan partisipasi dalam organisasi sebagai berikut:

Tabel 1. Tabel Deskripsi Statistik

\begin{tabular}{|l|c|c|c|c|c|}
\hline \multicolumn{1}{|c|}{ Variabel } & Obs & Mean & Standar Deviasi & Min & Max \\
\hline IPK & 111 & 3.4 & 0.3 & 2.5 & 4 \\
\hline WB (Menit/Hari) & 111 & 103.5 & 78.5 & 3 & 360 \\
\hline LK (Jam/Minggu) & 111 & 21 & 4.1 & 4.1 & 32 \\
\hline PO & 111 & 0.75 & 0.43 & 0 & 1 \\
\hline
\end{tabular}

Tabel 1 di atas menunjukan bahwa jumlah observasi sebanyak 111. Nilai minimum dari IPK mahasiswa sebesar 2,5, nilai maksimum sebesar 4, nilai rata-rata sebesar 3,4 dengan standar deviasi sebesar 0,3. Nilai minimum dari lama waktu yang dihabiskan untuk membaca sebesar 3 menit/hari, nilai maksimum sebesar 360 menit/hari, nilai rata-rata sebesar 103,5 menit/hari dengan standar deviasi 78,5 menit/hari. Nilai minimum dari lama waktu kuliah sebesar 4,1 jam/minggu, nilai maksimum sebesar $32 \mathrm{jam} /$ minggu, nilai rata-rata sebesar $21 \mathrm{jam} / \mathrm{minggu}$ dengan standar deviasi sebesar 4,1 jam/minggu. Variabel partisipasi dalam organisasi merupakan variabel dummy, maka variabel ini menggunakan statistik frekuensi, berbeda dengan ketiga variabel lainnya. Hasilnya sebagai berikut: 
Tabel 2. Tabel Statistik Frekuensi untuk PO

\begin{tabular}{|l|c|c|c|}
\hline \multicolumn{1}{|c|}{ PO } & Frequency & Percent & Cumulative Percent \\
\hline 0 & 28 & 25.23 & 25.23 \\
\hline 1 & 83 & 74.77 & 100 \\
\hline Total & 111 & 100 & \\
\hline
\end{tabular}

Berdasarkan tabel 2, jumlah mahasiswa yang mengikuti organisasi sebanyak 83 orang dan jumlah mahasiswa yang tidak mengikuti organisasi sebanyak 83 orang. Presentase mahasiswa yang mengikuti organisasi sebesar $74,77 \%$ dan presentasi mahasiswa yang tidak mengikuti organisasi sebesar $25,23 \%$. Hal ini menunjukan bahwa sebagian besar mahasiswa dalam penelitian ini mengikuti organisasi.

Untuk menganalisis bagaimana pengaruh lama waktu yang dihabiskan untuk membaca, lama waktu kuliah dan partisipasi dalam organisasi terhadap IPK yang diperoleh mahasiswa di Fakultas Ekonomi dan Bisnis Universitas Padjajaran, maka dilakukan pengujian model regresi data terlebih dahulu, yang hasilnya sebagai berikut:

Tabel 3. Tabel Hasil Regresi

\begin{tabular}{|l|c|c|c|}
\hline \multicolumn{1}{|c|}{ Variabel } & Besar Pengaruh & Standar Error & \multirow{2}{*}{$\boldsymbol{R}^{\mathbf{2}}$} \\
\hline WB & 0.0011212 & 0.0003612 & \\
LK & 0.0288029 & 0.0067737 & \multirow{2}{*}{0,2094} \\
\cline { 1 - 3 } PO & 0.1536938 & 0.648317 & \\
\hline Konstanta & 2.559667 & 0.1651465 & \\
\hline
\end{tabular}

Berdasarkan hasil regresi yang telah dilakukan, diperoleh nilai $\mathrm{R}^{2}$ sebesar 0,2094 . Nilai IPK tanpa dipengaruhi oleh variabel apapun adalah rata-rata sebesar 2,559667 satuan dan standar errornya sebesar 0,1651465 . Ketika waktu membaca naik sebesar satu menit per hari, ceteris paribus, maka IPK akan mengalami kenaikan sebesar 0,0011212 satuan dan standar error-nya sebesar 0,0003612. Sementara ketika lama kuliah naik sebesar satu jam per minggu, ceteris paribus, maka IPK akan mengalami kenaikan sebesar 0,0288029 satuan dan standar error-nya sebesar 0,0067737. Jika terdapat dua individu dengan waktu membaca dan lama kuliah yang sama, apabila individu 1 mengikuti organisasi maka IPK individu tersebut akan lebih tinggi rata-rata sebesar 0,1536938 satuan daripada individu yang tidak mengikuti organisasi dan standar error-nya sebesar 0,648317.

\section{b. Uji Asumsi Klasik}

i. Uji Multikolinearitas

Tabel 4. Tabel Hasil Uji Multikolinearitas

\begin{tabular}{|l|c|c|}
\hline \multicolumn{1}{|c|}{ Variabel } & VIF & 1/VIF \\
\hline WB & 1.03 & 0.975489 \\
\hline LK & 1.02 & 0.985039 \\
\hline PO & 1.02 & 0.981861 \\
\hline Mean VIF & 1.02 & \\
\hline
\end{tabular}

Berdasarkan hasil pengujian, nilai Mean VIF (Variance Inflation Factors) yang dihasilkan model sebesar 1,02 dengan nilai $R^{2}$ sebesar 0,2094. Nilai yang dihasilkan tersebut nominalnya lebih kecil daripada 5, yang menurut kriteria pengujian yang ada, jika nilai Mean VIF (Variance Inflation Factors) lebih kecil daripada 5 maka dalam model ini tidak terdapat masalah multikolinearitas. 


\section{ii. Uji Heteroskedastisitas}

Hasil uji heteroskedastisitas model menggunakan Breusch Pagan test (BP Test) menunjukan nilai LM sebesar 3,43 dan nilai $p$-value sebesar 0,3293. Sementara untuk nilai $X_{k}^{2}$ pada model ini sebesar 7,815 dan nilai $\alpha$ sebesar 0,05 (5\%). Jika nilai LM dibandingkan dengan nilai $X_{k}^{2}$, maka nilai LM lebih kecil daripada nilai $X_{k}^{2}$. Dan jika nilai $p$-value dibandingkan dengan nilai $\alpha$ maka nilai $p$ value lebih besar daripada nilai $\alpha$. Dengan kriteria Breusch Pagan test (BP Test) yang ada, dapat disimpulkan bahwa tidak terdapat masalah heteroskedastisitas dalam model.

\section{c. Uji Hipotesis}

i. $\quad$ Uji Signifikansi Parameter Individual (Uji Statistik t)

Dengan menggunakan $\alpha$ sebesar 0,05 dan derajat kebebasan (degree of freedom) sebesar 107 maka diperoleh nilai t tabel sebesar 1,980. Hasil pengujian antara nilai $t$ statistik dan $t$ tabel disajikan dalam tabel dibawah ini:

Tabel 5. Tabel Hasil Uji Statistik t

\begin{tabular}{|l|l|l|}
\hline Variabel & t statistik & Kesimpulan \\
\hline WB & 3,10 & Signifikan \\
\hline LK & 4,25 & Signifikan \\
\hline PO & 2,37 & Signifikan \\
\hline
\end{tabular}

Kesimpulan yang dapat ditarik dari tabel diatas adalah secara parsial seluruh variabel independen dalam model memiliki pengaruh yang signifikan terhadap variabel dependennya.

\section{ii. $\quad$ Uji Signifikansi Simultan (Uji Statistik F)}

Dengan menggunakan $\alpha$ sebesar 0,05 , derajat kebebasan numerator $\left(d f_{1}\right)$ sebesar 3 dan derajat kebebasan denominator $\left(d f_{2}\right)$ sebesar 107 maka diperoleh nilai $\mathrm{F}$ tabel sebesar 2,6802. Sedangkan nilai $F$ hitung yang diperoleh sebesar 9,45. Jika nilai $F$ hitung dan $F$ tabel dibandingkan maka nilai $\mathrm{F}$ hitung lebih besar daripada $\mathrm{F}$ tabel yang berarti secara simultan (bersama-sama) seluruh variabel independen dalam model berpengaruh secara signifikan terhadap variabel dependennya.

\section{iii. $\quad$ Uji Koefisien Determinasi $\left(R^{2}\right)$}

Dari hasil regresi diperoleh nilai $R^{2}$ sebesar 0,2094, yang artinya bahwa variasi dari seluruh variabel independen sebesar 20,94\% mampu menjelaskan variasi dari variabel dependen dan sisanya $79,06 \%$ dijelaskan oleh variabel lain diluar model.

\section{PENUTUP}

Berdasarkan hasil pengujian signifikansi parameter individual (uji statistik t) diatas, ditemukan bahwa lama waktu yang dihabiskan untuk membaca memiliki pengaruh yang positif dan signifikan pada $\alpha$ sebesar 0,05 terhadap IPK yang diperoleh mahasiswa di Fakultas Ekonomi dan Bisnis Universitas Padjajaran. Lama waktu kuliah memiliki pengaruh yang positif dan signifikan pada a sebesar 0,05 terhadap IPK yang diperoleh mahasiswa di Fakultas Ekonomi dan Bisnis Universitas Padjajaran. Dan partisipasi dalam organisasi memiliki pengaruh yang positif dan signifikan pada $\alpha$ sebesar 0,05 terhadap IPK yang diperoleh mahasiswa di Fakultas Ekonomi dan Bisnis Universitas Padjajaran. Berdasarkan hasil pengujian signifikansi simultan (uji statistik F), ditemukan bahwa lama 
waktu yang dihabiskan untuk membaca, lama waktu kuliah dan partisipasi dalam organisasi berpengaruh signifikan secara simultan (bersama-sama) terhadap IPK yang diperoleh mahasiswa di Fakultas Ekonomi dan Bisnis Universitas Padjajaran. Maka, dapat disimpulkan bahwa lama waktu yang dihabiskan untuk membaca, lama waktu kuliah dan partisipasi dalam organisasi merupakan faktor penting yang mempengaruhi besarnya IPK yang diperoleh mahasiswa.

\section{DAFTAR PUSTAKA}

Achmadi, R. (2007). Pengaruh Minat Terhadap Prestasi Belajar Mahasiswa Jurusan Perhotelan AKPINDO. Panorama Nusantara, 2(1), 35-42.

Amanah, L. T., Noviana, R., Sofiah, R., \& Chamdani, M. (2018). The Correlation Of Reading Interest To Learning Outcomes In Indonesia Learner In Class 5 of SDN 2 Karang Tanjung. 3rd National Seminar on Educational Innovation (SNIP 2018), 1(Snip), 248-254.

AR, M. (2017). Pengaruh Minat Baca terhadap Prestasi Belajar Siswa Sekolah Dasar. (10), 56-63. Retrieved from http://pasca.um.ac.id/conferences/index.php/sntepnpdas/article/view/843

Asmani, J. M. (2009). Jurus-jurus Belajar Efektif Untuk SMP dan SMA. Yogyakarta: DIVA Press.

Aunurrahman. (2010). Belajar dan Pembelajaran. Bandung: Alfabeta.

Baharuddin, J., \& Wahyuni, E. N. (2008). Teori Belajar dan Pembelajaran. Yogyakarta: Ar-Ruzz Media.

Budisetyani, I. G. (2005). Pengaruh Riward dan SistemKompetisi Terhadap Prestasi PemanahIndonesia. Anima, Indonesian PsychologicalJournal, 21(1), 53-65.

Dalman. (2013). Keterampilan Membaca. Jakarta: RajaGrafindo Persada.

Dalyono. (2005). Psikologi Pendidikan. Jakarta: Rineka Cipta.

Darmadi, H. (2012). Kemampuan Dasar Mengajar. Bandung: Alfabeta.

Depdikbud. (2016). Kamus Besar Bahasa Indonesia (KBBI). Retrieved April 19, 2019, from https://kbbi.web.id/minat

Djamarah, S. B. (2008). Strategi Belajar Mengajar. Jakarta: Rineka Cipta.

Djamarah, S. B. (2011). Psikologi Belajar (Edisi Revi). Jakarta: Rineka Cipta.

Gujarati, D. N., \& Porter, D. (2008). Basic Econometric. In Fifth Edition. The McGraw-Hill Series Economics.

Hamdani, M. A. (2011). Strategi Belajar Mengajar. Bandung: CV Pustaka Setia.

Hapsari, Sayidati \& Rachmawati, L. (2018). Pengaruh Minat Baca dan Penggunaan Gadget Terhadap Hasil Belajar Ekonomi Peserta Didik Kelas X IPS MA Al-Hidayah Bangkalan. Jupe, 6(2), 1722.

Hardi. (2014). PENGARUH MINAT MEMBACA BUKU TERHADAP HASIL BELAJAR MAHASISWA BKK AKUNTANSI. 561-565.

Herkusumo, A. P. (2009). Hubungan antara pengaturan diri dalam belajar, self efficacy, lingkungan 
belajar di rumah, dan inteligensi dengan prestasi belajar suatu studi perbandingan antara siswa berbakat dengan siswa biasa kelas satu SMA di Jakarta. Jurnal Keberbakatan Dan Kreativitas, $3(1)$.

Komarudin, D. (2018). Hubungan Antara Kreativitas Dengan Prestasi Belajar Siswa. Psympathic: Jurnal Ilmiah Psikologi, 4(1), 278-288. https://doi.org/10.15575/psy.v4i1.2196

Kuncoro, M. (2009). Metode Riset untuk Bisnis dan Ekonomi. In Penerbit Erlangga, Jakarta.

Listariono. (2010). Peranan Perpustakaan Sekolah Dalam Upaya Menumbuhkan Minat Baca Siswa. (April), 1-13.

Nasution, S. (1996). Psikologi Pendidikan. Jakarta: PT.Bumi Aksara.

Nelsusmena. (2010). Hubungan Motivasi Berprestasi Dengan Prestasi Belajar Sejarah. Jurnal Educatio Indonesia Tahun 18, No. 2, Desember.

Noor, J. (2014). ANALISIS DATA PENELITIAN EKONOMI \& MANAJEMEN. In ANALISIS DATA PENELITIAN EKONOMI \& MANAJEMEN (pp. 19-52). Jakarta: PT Grasindo.

Nugroho, F. A. (2012). Faktor-Faktor Yang Mempengaruhi Prestasi Belajar Pemasangan Dasar Instalasi Listrik Siswa Kelas X Teknik Instalasi Tenaga Listrik SMK Negeri 1 Sedayu.

Nurhadi. (2008). Membaca Cepat dan Efektif. Bandung: Sinar Baru.

Parmadani, T. S., \& Latifah, L. (2016). Pengaruh Minat Baca, Sumber Belajar dan Lingkungan Teman Sebaya Terhadap Prestasi Belajar Ekonomi. Economics Education Analysis Journal, 4(2), 496-508. https://doi.org/http://dx.doi.org/10.1093/ageing/25.2.97

Purwanto, M. N. (2007). Psikologi Pendidikan. Bandung: Remaja Rosdakarya.

Rahim, F. (2009). PENGAJARAN MEMBACA DI SEKOLAH DASAR (2nd ed.). Bumi Aksara.

Sardiman, A. M. (2000). Interaksi \& motivasi belajar mengajar. Jakarta: PT RajaGrafindo Persada.

Sari, N., \& Wakijo. (2017). Pengaruh Pemanfaatan Perpustakaan Sekolah Dan Minat Baca Siswa Terhadap Hasil Belajar IPS Terpadu Siswa Kelas VII Semester Genap SMP Negeri 2 Metro Tahun Pelajaran 2016/2017. Pengaruh Kualitas Sekolah, Bauran Promosi Dan Lokasi Sekolah Terhadap Jumlah Siswa Sma Swasta Di Kabupaten Pringsewu Tahun 2016/2017, 5(1), 105116.

Siregar, A. R. (2008). Pengembangan Kebiasaan Membaca.

Siswati. (2010). Minat Membaca pada Mahasiswa. Jurnal Psikologi Undip, 8(2), 11.

Slameto. (2010). Belajar dan Faktor-Faktor Yang Mempengaruhinya (Revisi). Jakarta: Rineka Cipta.

Slavin, R. E. (2000). Educational Psychology: Theory and Practice (Sixth Edit). Boston: Allyn and Bacon.

Sriyono, H. (2011). Program Bimbingan Untuk Membantu Meningkatkan Kemandirian Belajar Siswa. Jurnal SOSIO E-KONS, III(2).

Sudjana, N. (2013). Penilaian Hasil Proses Belajar Mengajar. Bandung: PT Remaja Rosdakarya.

Suharsimi, A. (2010). Prosedur Penelitian : Suatu Pendekatan Praktik (Edisi Revisi). In Jakarta: Rineka Cipta (Vol. 1). https://doi.org/10.1017/CBO9781107415324.004 
Suprayekti. (2010). Keterampilan Belajar Mahasiswa. Jurnal Perspektif Ilmu Pendidikan. Vol. 22 Th. XIII Oktober, 22.

Suryabrata, S. (2005). Psikologi Pendidikan. Jakarta: Rajawali Pers.

Suyono, \& Hariyanto. (2011). Belajar dan Pembelajaran. Bandung: PT Remaja Rosdakarya.

Syah, M. (2010). Psikologi Pendidikan dengan Pendekatan Baru. Bandung: PT Remaja Rosdakarya.

Tarigan, H. G. (2008). Menyimak Sebagai Suatu Ketrampilan Berbahasa. Bandung: Angkasa.

Tarno. (2010). Peningkatan Prestasi Belajar Matematika Melalui Pembelajaran Kontektual. Jurnal Ilmiah Guru "COPE”, Nomor 02/Tahun XIV/November.

Timperley, H., \& Alton-Lee, A. (2008). Reframing Teacher Professional Learning: An Alternative Policy Approach to Strengthening Valued Outcomes for Diverse Learners. Review of Research in Education, 32(1), 328-369. https://doi.org/10.3102/0091732X07308968

Tu’u, T. (2004). Peran Disiplin pada Perilaku dan Prestasi Siswa. Jakarta: Grasindo.

van Geel, M., Keuning, T., Visscher, A. J., \& Fox, J.-P. (2016). Assessing the Effects of a SchoolWide Data-Based Decision-Making Intervention on Student Achievement Growth in Primary Schools. American Educational Research Journal, 53(2), 360-394. https://doi.org/10.3102/0002831216637346

Wahadaniah, H. (1997). Perpustakaan Sekolah sebagai Sarana Pengembangan Minat dan Kegemaran Membaca. Jakarta: Departemen Pendidikan dan Kebudayaan.

Widodo. (2000). Kamus Ilmiah Populer. Yogyakarta: Absolut.

Widyasmoro, A. (2014). Pengaruh Minat Baca Terhadap Prestasi Belajar PKN Siswa Kelas V SD di Desa Pagergunung Kabupaten Pemalang Tahun Ajaran 2013/2014. Retrieved from https://www.bps.go.id/dynamictable/2018/05/18/1337/persentase-panjang-jalan-tol-yangberoperasi-menurut-operatornya-2014.html

Winkel, W. S. (2004). Psikologi Pengajaran. Yogyakarta: Media Abadi.

Wirantasa, U. (2018). Pengaruh Kedisiplinan Siswa Terhadap Prestasi Belajar Matematika. Formatif: Jurnal Ilmiah Pendidikan MIPA, 7(1), 83-95. https://doi.org/10.30998/formatif.v7i1.1272

Wiryodijoyo, S. (1989). Membaca: Strategi Pengantar dan Tekniknya. In Depdikbud. Jakarta: FKIP Universitas Bengkulu.

Witherrington. (1959). Education Pschological. Penguin Educational.

Wooldridge, J. M. (2012). Introductory Econometrics: A Mordern Approach, Fifth Edition. In Cengage Learning (5th Editio, Vol. 42). https://doi.org/10.2307/2553001

Wulan, R. (2000). Hubungan Antara Pengasuhan Orang Tua Dengan Prokrastinasi Akademik Pada Remaja SMU. 